\title{
Nadia Mayahi
}

Department of English Language and Literature

Shahid Chamran University of Ahvaz, Ahvaz, Iran

n-mayahi@stu.scu.ac.ir

\section{Alireza Jalilifar *}

Department of English Language and Literature

Shahid Chamran University of Ahvaz, Ahvaz, Iran

a.jalilifar@scu.ac.ir

\section{SELF-DENIGRATION IN DOCTORAL DEFENSE SESSIONS: SCALE DEVELOPMENT AND VALIDATION}

\section{Abstract}

The dissertation defense as a complicated conflict-prone context entails the adoption of elegant interactional strategies, one of which is self-denigration. This study aimed to develop and validate a self-denigration model that fits the context of doctoral defense sessions in applied linguistics. Two focus group discussions provided the basis for developing this conceptual model which assumed ten functions for self-denigration, namely good manners, modesty, affability, altruism, assertiveness, diffidence, coercive self-deprecation, evasion, diplomacy, and flamboyance. These functions were used to design a 40 -item questionnaire on the attitudes of applied linguists concerning self-denigration in defense sessions. The confirmatory factor analysis of the questionnaire indicated the predictive ability of the measurement model. The findings of this study suggest that self-denigration in doctoral defense sessions is the social representation of the participants' values, ideas and practices adopted as a negotiation strategy and a conflict management policy for the purpose of establishing harmony and maintaining resilience. This study has implications for doctoral students and academics and illuminates further research on self-denigration in other contexts.

\section{Key words}

academic discourse, politeness, self-denigration, grounded theory, dissertation defense.

\footnotetext{
* Corresponding address: Alireza Jalilifar, Dept. of English Language \& Literature, Faculty of Letters \& Humanities, Shahid Chamran University of Ahvaz, Iran.
} 


\section{INTRODUCTION}

The dissertation defense session is a mandatory oral examination in the higher education system of many countries. It is the culminating genre of doctoral education (Mežek \& Swales, 2016). This is a communicative event which is held to assess the doctorateness of a dissertation by a panel of academics (Trafford \& Leshem, 2009). In this criticism-prone context, the participants' main purpose is "the performing of academic personae, be they candidates, committee members, speakers or questioners" (Mežek \& Swales, 2016: 362). In non-Anglophone contexts like Iran, where English is a foreign language (EFL), besides conforming to the academic rituals of the session, the participants observe their local cultural norms and values in dealing with the requirements of the setting.

An important feature of the talk in this context is that the participants, especially the examiners, "wear their scholarship sufficiently lightly so as not to alienate the other participants" by trying to be "careful and thoughtful human beings" (Mežek \& Swales, 2016: 363). This characteristic feature of the defense is maintained by adopting different speech acts and politeness strategies such as selfdenigration, which is conventionally perceived as an expression of good manners and deference (Gu, 1990; Kádár, 2010; Sharifian, 2017). However, due to the facethreatening context of the defense with all its evaluative comments, self-denigration seems to be more than a politeness strategy. Contemporary studies on selfdenigration confirm novel functions of this phenomenon for which the existing models fail to account, such as seeking solidarity, seeking comfort, showing off, and managing interactional troubles (Kádár \& Zhou, 2021; Speer, 2019).

In light of what has been mentioned above and the unprecedented variations in the functions of self-denigration, this phenomenon deserves more attention, particularly in EFL contexts where the participants are influenced by their local cultures. Therefore, the development of a more thorough model encompassing different functions of self-denigration and its affordances and constraints seems indispensable. As research on the discoursal properties of defense sessions, particularly in non-Anglophone contexts, is scarce (Mežek \& Swales, 2016), this study seeks to improve our theoretical understanding and empirical knowledge of the interactions in the challenging and controversial context of defense sessions in terms of self-denigration. This is accomplished using the grounded theory methodology, which is an "inductive, comparative, emergent, and open-ended approach" (Charmaz, 2014: 12) to data collection and analysis. It is a philosophical position which focuses "on the meanings ascribed by participants" and revolves around "the views, values, beliefs, feelings, assumption, and ideologies of individuals" (Creswell, 2012: 429). The methodology offers a set of guidelines for coding the data which can lead to a theory grounded in the data. In an attempt to develop a measurement model for self-denigration, the current study strives to answer the following questions: 
1) How is self-denigration regarded by the defense session participants?

2) Under what conditions is self-denigration adopted? What is the significance of denigrating oneself in a defense session?

3) How do the participants think, feel, and act while they denigrate themselves in a defense session?

4) Is the constructed measurement model valid in terms of predicting selfdenigration in defense sessions?

\section{INTERACTIONS IN IRANIAN EFL DOCTORAL DEFENSE SESSIONS}

A doctoral defense session has a different speech exchange system compared to ordinary conversations, which involve a predetermined sequence of events and different turn-taking practices providing the participants with different opportunities to take part in the interaction. Defense session interactions are amalgamations of cultural and professional practices (Izadi, 2016). Each section has its own interaction style. The opening interaction is a ceremonial speech in which the supervisor formally introduces the candidate, the dissertation and the reviewers, and welcomes the participants. The next stage is devoted to presenting a summary of the dissertation by the candidate who is expected to "proudly defend the document" using persuasive scholarly presentation (Swales, 2004: 169). The main part of a defense is the question and answer section with a critical academic style. Typically, following the rules of conversation, one examiner speaks at a time. The candidate might be invited to immediately respond to the comments raised by each examiner, or he/she might be asked to take down all the questions voiced by the examiners and subsequently respond to the questions in order. However, due to the argumentative nature of the session, the participants might also use overlap and interruption as a strategy for turn-taking because "turns at talk are emergent in the common sense of coming into being in the moment of inter-action" (Arundale, 2020: 46). Thus, for different purposes such as approving or rejecting what someone is saying, the participants may take up the turn without being nominated.

The question and answer section of the defense is the point at which the examiners exhibit their knowledge and expertise on the topic by "questioning, giving critical comments, disagreeing and calling attention to mistakes" (Don \& Izadi, 2011: 3784). Accompanied by an exchange of pleasantries, the informal aspect of the interaction is used "to lubricate the wheels of the genre" and maintain "solidarity and cooperation" while the academic dimension is ascribed to the purpose-driven nature of the defense, which is "to explore seriously the relevant issues in both considerable depth and breadth" (Swales, 2004: 170). The defense proper is the most challenging part for the candidate, who is required to provide adequate explanations and justifications for the issues raised by the examiners to prove his/her "original contribution to knowledge" (Swales, 2004: 169). 
Because of its criticism-generating nature, the interaction in this part evokes face-threating acts that compel the participants to resort to different face maintaining and face supporting acts (Don \& Izadi, 2011). In some instances, these circumstances lead to over-politeness, which is mainly concerned with the interpersonal aspect of the talk in a defense session. Over-politeness is one of the socially appropriate rhetorical strategies which seems to make Iranian defense sessions distinct from Western defenses. It is manifested in a situation where the participants insist on the observance of formalities and are excessively concerned with creating relational connections with their interlocutors. Compliments and compliment responses are occasions which are prone to over-politeness in an Iranian defense session because of the discrepancy between Persian societal roles and professional institutional roles (Izadi, 2016).

As the main goal of the defense is not to establish interpersonal relationships but to defend one's claims, adopting too much formality and ritual politeness called taarof in Persian might be perceived as irrelevant, inapposite, inadequate, and overpolite (Izadi, 2016). The cultural schema of taarof spreads more subjectivity and implicitness in Iranian defense session interactions as compared with Western defenses, in which the interactions are more objective and explicit. Still, this extreme politeness can be conceived of as conformity to the conventional norms of the setting and act as a relational ritual practice (Kádár, 2013) which is associated with the Iranian notion of politeness. Awareness of these cultural rhetorical differences is important as noncompliance with the norms might affect the final result and the participants' interepretation of the defense interactions.

The closing of the defense session consists of two parts, the evaluation segment and the results, usually conducted in Persian. The evaluation section, which comes under "occluded genres" (Swales, 2004: 18), is held privately by the supervisor, the advisor, the representative of the higher education department, and the examiners. The candidate and the other participants are asked to leave the room so that the committee members can evaluate the dissertation and decide on the score. Finally, in the results section, when everyone is invited back to the room, the supervisor announces the result.

\section{SELF-DENIGRATION}

Self-denigration is a politeness maxim performed by denigrating self or elevating others (Gu, 1990). Influenced by communities' diverse social values (Page, 2019), it has different meanings in different contexts and cultures (Kádár, 2019; Yu, 2013; Zare, 2016). It is usually equated with the cultural schema of modesty or humbleness (Sharifian, 2008), used to convey esteem or respect (Gu, 1990; Sharifian, 2017), and build rapport (Walkinshaw, Mitchell, \& Subhan, 2019), particularly in Eastern cultures. It is also believed to be a strategy for receiving more compliments (Spencer-Oatey, Ng, \& Dong, 2008). Self-denigration is a context- 
sensitive and intersubjective phenomenon (Page, 2019). A number of situational factors determine the use of self-denigration such as "the relative status of individuals, degree of intimacy, presence or absence of evaluation concerns, prior interpersonal experiences, and different social settings" (Kim, 2014: 2). By way of example, one of the situations in which speakers instantiate self-denigration, particularly in Eastern cultures, is when someone receives a compliment or praise for an achievement, a performance, or success (Allami \& Montazeri, 2012; Drbseh, 2015; Sharifian, 2005, 2008). Review of the literature in this area revealed a cline of self-denigration on which Western and Eastern cultures are plotted at the two extreme ends. However, regardless of the individuals' cultures and languages, they observe different degrees and forms of self-denigration co-constructed based on the context, which is due to the dynamicity of the language and the intentions behind self-denigration. Furthermore, the focus on the boundaries of self-denigration has moved away from relatively narrow considerations and it is difficult to determine clear-cut borderlines between different aspects of self-denigration (interactional, dispositional, and situational). As a matter of fact, it seems that the above-mentioned dimensions can coexist in the underlying intentions behind denigration in an interaction. Therefore, taking the local and dynamic nature of the interaction into consideration, self-denigration in some situations might be more interactional, and in some other circumstances it might be more situational, or dispositional.

Changes in our views of globalization have also precipitated new patterns of self-denigration to occur. For instance, Eslami, Jabbari, and Kuo, (2019) and Kádár and Zhou (2021) showed that in Eastern cultures, besides the ceremonial function of showing deference and modesty, self-denigration fulfills a number of semiconventional and unconventional socio-pragmatic functions. These novel functions are even expressed by newly-coined conventionalized self-denigrating expressions.

In his cross-cultural study of self-denigration in Persian and Australian English, Sharifian (2005) observed that, in Persian, the receivers of the praise do not accept the compliment; instead, they mainly attribute what is being complimented to others (God, family members, teachers, etc.), deny it, or simply downgrade it in order to be regarded as modest and enhance other's face. This is mainly the case in face-to-face interactions, and compliments in Persian digital communications (e.g. on Facebook) seem to be used with a different intention, for instance, as a selfpromotion strategy (Eslami et al., 2019). In Sharifian's study, Australians, however, showed more tendency toward accepting compliments. Furthermore, they portrayed self-denigrating comments in these circumstances as dishonest, exaggerated, or ironic. In other studies, downgrading compliments on topics like possessions and character, for instance, was reported as the most frequent compliment response by Australians (Tang \& Zhang, 2009). Therefore, even in the same cultural groups, people might have different interpretations of selfdenigration because these cultural schemas "are represented in a distributed fashion across the minds in a cultural group" (Sharifian, 2003: 187). 
A number of studies have explored the interactional aspect of self-denigration focusing on first language speakers like Japanese, Chinese, Korean, and English (Gu, 1990; Kádár, 2010; Kim, 2014; Spencer-Oatey et al., 2008; Yu, 2013; Zare, 2016). Analyzing a corpus of natural conversations of male university students, Zare (2016) studied self-denigrating humor or self-mockery and how it was responded to in Persian. The results indicated that self-denigrating humor was used as a response to a former humor or as a reaction to embarrassment for saving one's own or other's face, and to bring a shared amusement to the conversation. According to the results of this study, self-denigration functions as an interactional strategy to build a sense of in-group solidarity between the interlocutors.

Similar studies on self-denigration have focused on speakers of English as a second language (Sharifian, 2005, 2008; Walkinshaw et al., 2019). For example, selfdenigration in lingua franca interactions of Asians has been investigated by Walkinshaw, Mitchell, and Subhan (2019). The study showed that Asians tend to self-denigrate in "informal, non-role-assigning, non-task-focused interactions" (p. 40 ) in their English as a lingua franca talk to manage the interpersonal relationships between the interlocutors. According to this study, self-denigration occurs as a first or a second turn in an interaction. The first turn self-denigration can be a standalone utterance or an utterance following a speaker's positive self-evaluation. As a second turn, self-denigration is believed to be a relational strategy used as a response to compliments, criticisms, or neutral statements and questions.

Based on the circumstances, the participants rely on their own pragmatic knowledge of the context and decide if an utterance is polite, impolite, or politic. Leech (2014) presumes the existence of a cline of politeness, and distinguishes between socio-pragmatic and pragma-linguistic politeness. The former refers to the interlocutors' pragmatic awareness of the situation while the latter is concerned with the participants' speech intentions and the linguistic items they use to express those intentions. It appears from the literature that the pragmatic boundaries of selfdenigration have expanded. Different intentions might emerge as the participants are co-constructing meaning and actions in the course of the interaction. Therefore, taking the local and dynamic nature of the interaction into consideration, this study contributes to the field by exploring self-denigration in Iranian applied linguistics doctoral defense sessions, mainly by developing a scale for exploring the intentions of the defense participants and their perceptions of self-denigration.

\section{METHOD}

\subsection{Data and participants}

This mixed-methods study is part of a larger grounded theory research which focuses on self-denigration in the interactions of applied linguistics doctoral defense 
sessions. In this study, applied linguistics is used as a general term covering the two disciplines of English language teaching and translation studies. "In a broad sense, applied linguistics is concerned with increasing understanding of the role of language in human affairs" (Wilkins, 1999: 7). It draws "from numerous outside sources, such as psychology, education, and sociology, and which embraces myriads of interrelated groups, ranging from TESOL, corpus linguistics, second language acquisition, English for Academic Purposes (EAP), to the sociology of English language teaching" (Hadley, 2017: 11). To gain insights into the "norms, values, and experiences" (Hughes \& DuMont, 1993: 775) of defense session participants concerning self-denigration, two almost homogeneous focus group discussions (FG) were conducted (Table 1).

\begin{tabular}{|c|c|c|c|c|c|c|c|}
\hline \multirow{2}{*}{$\begin{array}{l}\text { Focus } \\
\text { groups }\end{array}$} & \multirow{2}{*}{ Participants } & \multirow{2}{*}{$\begin{array}{l}\text { Total } \\
\text { time } \\
(\mathrm{min})\end{array}$} & \multirow{2}{*}{$\begin{array}{c}\text { Total } \\
\text { number }\end{array}$} & \multicolumn{2}{|c|}{ Gender } & \multirow{2}{*}{$\begin{array}{c}\text { Average } \\
\text { age }\end{array}$} & \multirow{2}{*}{$\begin{array}{c}\text { Average years } \\
\text { of teaching } \\
\text { experience }\end{array}$} \\
\hline & & & & Males & Females & & \\
\hline FG1 & Faculty Members (FM) & 120 & 8 & 6 & 2 & 52.8 & 21.5 \\
\hline $\mathrm{FG} 2$ & Doctoral graduates (DG) & 90 & 7 & 6 & 1 & 42.5 & 17.2 \\
\hline
\end{tabular}

Table 1. Focus group participants' demographic information

The focus group discussions consisted of a small number of semi-structured questions designed based on Krueger and Casey's (2015) categories, including:

1. Do you self-denigrate in your everyday life? How? Why?

2. What does self-denigration mean to you?

3. Do participants in the academic context of a defense session self-denigrate? How?

4. Who do you think tends to self-denigrate more in a defense session, the examiner, the supervisor/advisor, or the candidate? Why?

5. Do participants self-denigrate to achieve relational connection with or separation from their interlocutors? How?

6. Is there anything else you would like to say about why participants self-denigrate in a defense session?

To establish a comfortable and collegial atmosphere, and ensure the smooth flow of communication, the focus group discussions were conducted in Persian. The questions were originally raised in English and the participants were free to respond in Persian or English. The participants switched to English mainly when they wanted to use academic terminology. To promote active participation, the moderator used a variety of techniques, such as "probing silent members to join the discussion, asking follow-up questions, using open-ended or indirect techniques" (Galloway, 2020: 291). As a matter of fact, these questions functioned as a point of departure and the discussions led to more questions and discussions which helped the researchers formulate the codes and conceptual categories. 


\begin{tabular}{|c|c|c|c|c|c|c|c|c|}
\hline \multirow{2}{*}{ Questionnaire } & \multirow{2}{*}{$\begin{array}{c}\text { Total } \\
\text { number of } \\
\text { respondents }\end{array}$} & \multicolumn{2}{|c|}{ Gender } & \multirow{2}{*}{$\begin{array}{l}\text { Average } \\
\text { age }\end{array}$} & \multirow{2}{*}{$\begin{array}{c}\text { PhD } \\
\text { holders }\end{array}$} & \multirow{2}{*}{$\begin{array}{c}\text { PhD } \\
\text { students }\end{array}$} & \multirow{2}{*}{ Examiners } & \multirow{2}{*}{$\begin{array}{c}\text { Supervisors/ } \\
\text { Advisors }\end{array}$} \\
\hline & & Males & Females & & & & & \\
\hline Pilot & 35 & $\begin{array}{c}17 \\
(48.57 \%)\end{array}$ & $\begin{array}{c}18 \\
(51.43 \%)\end{array}$ & 37.83 & $\begin{array}{c}16 \\
(45.71 \%)\end{array}$ & $\begin{array}{c}19 \\
(54.28 \%)\end{array}$ & $\begin{array}{c}7 \\
(20 \%)\end{array}$ & $\begin{array}{c}8 \\
(22.85 \%)\end{array}$ \\
\hline Final & 218 & $\begin{array}{c}123 \\
(56.42 \%)\end{array}$ & $\begin{array}{c}95 \\
(43.58 \%)\end{array}$ & 40.11 & $\begin{array}{c}136 \\
(62.39 \%)\end{array}$ & $\begin{array}{c}82 \\
(37.61 \%)\end{array}$ & $\begin{array}{c}61 \\
(27.98 \%)\end{array}$ & $\begin{array}{c}57 \\
(26.14)\end{array}$ \\
\hline
\end{tabular}

Table 2. Demographic information of questionnaire respondents

The findings of the focus groups were used to determine different aspects of selfdenigration, conceptualize a model, and develop a questionnaire. The constructed questionnaire was administered twice. First, as a pilot questionnaire, it was validated by nine applied linguistics academics and then was sent to a representative sample of 100 applied linguistics doctoral students, recent graduates and scholars chosen randomly from the PhD members of the Teaching English Language and Literature Society of Iran (TELLSI) from whom only 35 members filled this questionnaire (Table 2). After collecting and analyzing the data, and determining the internal consistency of the questionnaire $(\alpha=.92)$ the main questionnaire was administered to a larger sample of respondents chosen through purposive sampling. To optimize the response rate, the final questionnaire was not only sent to the PhD holder and student members of TELLSI and applied linguistics academics but was also sent to Applied Linguistics, Teaching English as a Foreign Language, and Translation Studies social media groups and channels (i.e. WhatsApp and Telegram applications) asking doctoral students and graduates to fill out the form and forward it to others. After two weeks, 246 questionnaires were filled and returned, of which 28 questionnaires were excluded because they were completed by BA or MA holders and the remaining 218 questionnaires were analyzed.

\subsection{Procedure}

The first step in analyzing the data was transcribing, coding, and analyzing the focus group discussions through conducting multiple levels of coding in a recursive fashion. The data from the two focus groups were constantly compared and contrasted with each other and with the researchers' field notes and memos (Charmaz, 2014). The detailed analysis of the discussions yielded valuable data regarding the meanings, characteristics, functions, and the linguistic and nonlinguistic representations of self-denigration. These findings were categorized to construct a conceptual model.

Then, a 40-item questionnaire was designed based on the categories of the conceptual model to explore the attitudes of a wider population concerning selfdenigration. Four items were designed based on the first four recurrent codes of each category. For a confirmatory factor analysis (CFA), at least 3-4 indicators per factor or 
function are necessary (Boomsma, 1985; Marsh \& Hau, 1999). The questionnaire was administered in Persian to stay faithful to the focus group participants' original ideas and avoid any misunderstandings or communicative conflict that may occur due to translating the items into English. The respondents' attitudes were measured on a five-point Likert scale (on a continuum from 'strongly agree' to 'strongly disagree').

To obtain specific responses and encourage the respondents to make a decision, even number scaling was used for the main questionnaire (Cohen, Manion, \& Morrison, 2007). Therefore, based on the results of the pilot questionnaire and the comments received from the respondents, the undecided option was removed. The researchers tried to design impersonal items for the questionnaire as the aim of the survey was the identification of the functions. In addition, the questionnaire items did not address any of the defense session participants to avoid preconceptions and biases of the researchers and to decrease the level of threat or sensitivity which would provoke negative emotions or insincere responses from the participants.

The link for the online pilot questionnaire was emailed and texted to the representative sample (100 members of TELLSI). Thirty-five respondents completed the pilot questionnaire. Researchers suggest a sample of 30 participants as the "reasonable minimum recommendation for a pilot study where the purpose is preliminary survey or scale development" (Johanson \& Brooks, 2009: 399). The final questionnaire was completed by 218 applied linguists. For CFA models with 3 or 4 indicators per factor, the sample size should not be less than a hundred; otherwise, minor effects might sometimes falsely indicate statistical significance (Boomsma, 1985; Marsh \& Hau, 1999). In sample sizes less than 200, the chi-square may fail to reject an unfitting model while with a too large sample may falsely reject an adequate model (Gatignon, 2010; Singh, Junnarkar, \& Kaur, 2016). Therefore, researchers suggest a sample between 200 (MacCallum \& Austin, 2000) and 300 (Tabachnick \& Fidell, 2013) respondents.

The construct validity and the internal consistency of the questionnaire were calculated. To confirm the scale and to see whether the results of the quantitative analysis of the questionnaire were consistent with the researchers' understanding of the construct in the conceptual model composite reliability, convergent validity, and discriminant validity of the measurement model were assessed. Multi-level confirmatory factor analysis was also conducted leading to the deletion of a number of items in the final analysis.

\section{RESULTS AND DISCUSSION}

\subsection{Building a conceptual model}

In the formal context of an oral defense, each interlocutor has a specific hierarchical role to play (e.g. candidate, supervisor, examiner, etc.). As such, due to "conflicting face needs" (Hay, 2001: 74), the participants find themselves in a politeness 
predicament wherein observing politeness turns into a challenging situation. According to the analysis of the focus group discussions in this study, selfdenigration is one of the interactional strategies adopted by defense participants. As they argued, they self-denigrate based on the requirements of the session, their interlocutors, and their own institutional roles in the session.

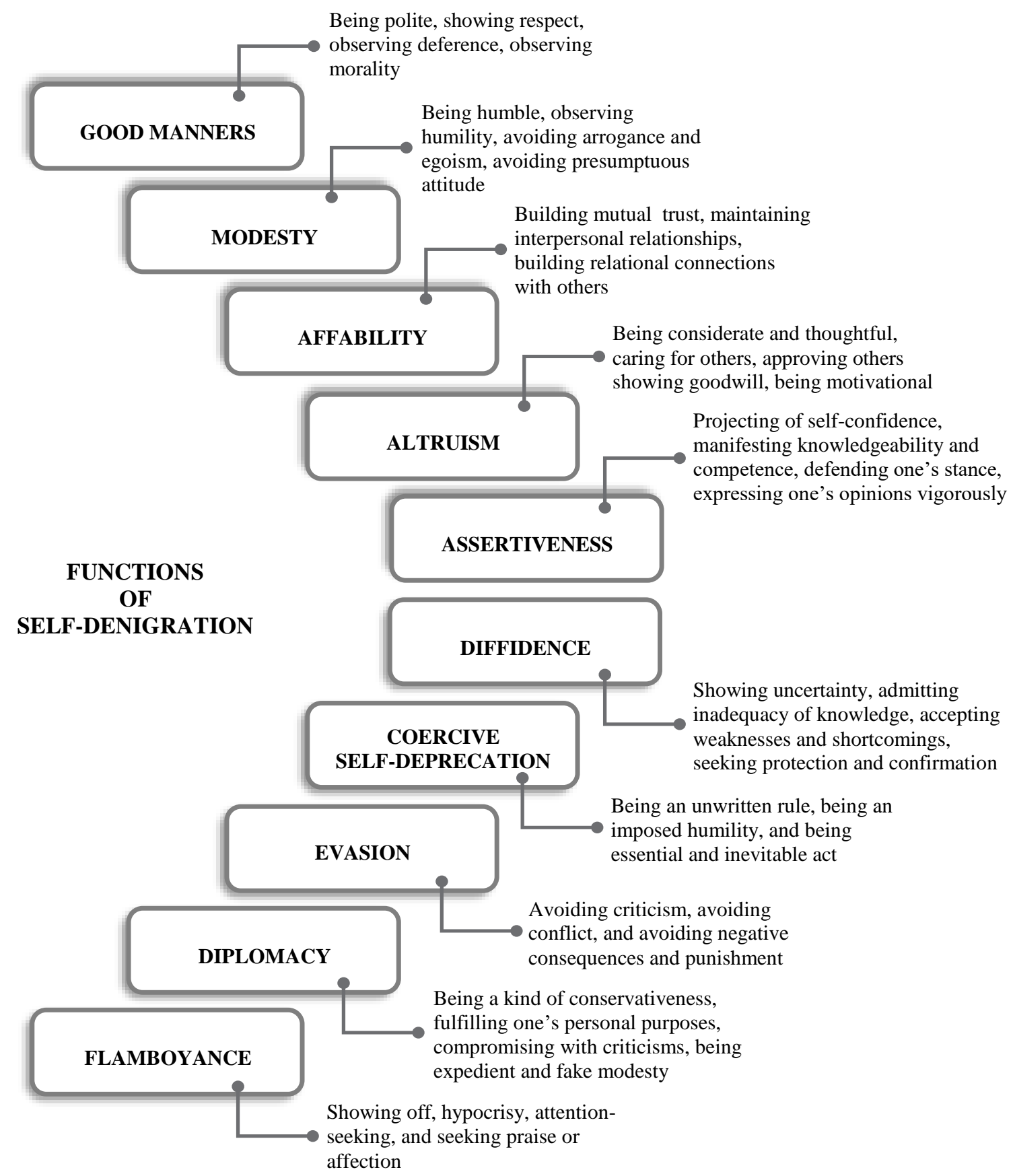

Figure 1. Conceptualization of functions of self-denigration in doctoral defense sessions 
The qualitative analysis of the data revealed that self-denigration functions as a social representation which is defined as a "system of values, ideas, and practices" of a community (Moscovici, 1973: xiii). The analysis of the focus group discussions resulted in a nuanced conceptualization of self-denigration. Figure 1 above shows the functions of self-denigration and provides examples of the focus groups' participants' attitudes for each of the functions. As the focus group participants stated, the borderlines between these intentions are hazy in that the defense session context is complicated and individuals might have different intentions to pursue in each circumstance. The hypothesized model in this context predicted a number of intentions or functions for self-denigration: Good Manners, Modesty, Affability, Altruism, Assertiveness, Diffidence, Coercive Self-deprecation, Evasion, Diplomacy, and Flamboyance (Figure 2).



Figure 2. Conceptualization of self-denigration in doctoral defense sessions 
Using the bottom-up approach, the participants' ideas were grouped and categorized based on their similarities and then assigned a title. For instance, codes denoting friendliness, which is the basis of building relational connections with others, were categorized under Affability while codes indicating goodwill, considerateness, and thoughtfulness were classified as Altruism. It is noteworthy that, as coding in grounded theory is done in a recursive and iterative manner, the codes were categorized and recategorized several times during the initial, focused, and theoretical phases of coding. The first five functions were sub-categorized under a more general function called Social Decorum. Evasion and Diplomacy were also considered as the two subsets of a higher category, that is Contrived Modesty. The following extracts from the interactions of the focus group discussions, with their English translations, led to the above-mentioned functions:

(1) Good Manners:

يه جور ايى به همون تعارف و اينا شايد بشه ربطش داد جون ما ابر انبا خيلى عادت داريم تعارف بكنيم، شكسته نفسى بكنيم. [Somehow, we can relate it to comity and things like that because we Iranians are accustomed to comity and self-denigration.]

(2) Modesty:

$$
\text { افر ادى كه به نظرم توى فر هنح ما از نو اضع استفاده نمى كنن، فكر مي كنم يه جور ايبى مغرور به نظر ميان. }
$$

[I think those who do not observe modesty in our culture seem to be kind of arrogant.]

(3) Affability:

اinterpersonal relationship ه هين هون.

[This is the same as the interpersonal relationship.]

(4) Altruism:

رعايتش مي كنه. در و اقع داره بهش لطف مي كنه. كمكش مي كنه.

[He/she is being considerate of him/her. In fact, he/she is being kind to him/her. Helping him/her.]

(5) Assertiveness:

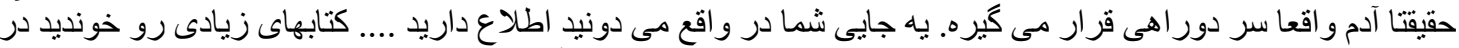

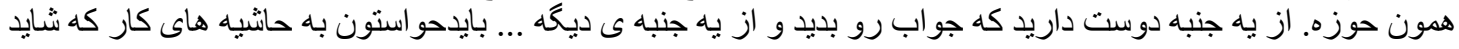

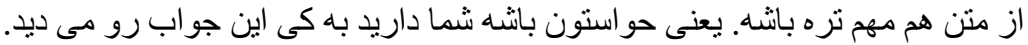

[You really find yourself at a crossroads. In some instances you are actually sure of your knowledge. You have read a lot of books in that area. On the one hand, you like to respond and on the other hand ... you have to consider the peripheral issues which might even be more important than the work. I mean you have to be careful who you are talking to.]

(6) Diffidence:

فكر مى كنم به خود اين epistemology شخص داور يا استاد راهنما هم بستخى داره. مثلا من ديدم آقاى دكتر ...

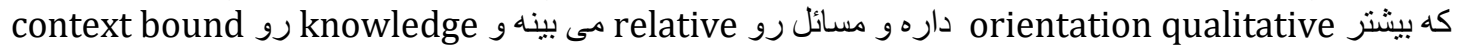

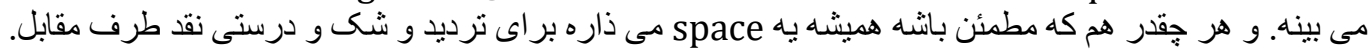

[I think it also depends on the epistemology of the examiner or the supervisor. For example, I've seen Dr...., who mainly has a qualitative orientation and sees things as 
relative and sees knowledge as context-bound. No matter how sure he is, he leaves some space for his own doubt and the accuracy of the other parties' criticism.]

(7) Coercive self-deprecation:

من احساس مى كنم كاهى اوقات مدكنه اين ديكته شده باشه و توصيه اي باشه. يعنى بعضى وقتها اين توصيه بشه از سمت

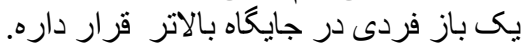

[I feel that it can sometimes be dictated and advised. That is, it can be advised by someone who is in a higher position.]

(8) Evasion:

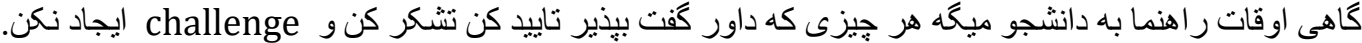

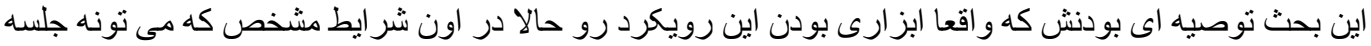

$$
\begin{aligned}
& \text { دفاع باشه رو نشون ميده. }
\end{aligned}
$$

[Sometimes the supervisor tells the student to accept, confirm, and appreciate whatever the examiners suggest, and don't create a challenge. That it's a recommendation actually shows its instrumentality particularly in defense sessions.]

(9) Diplomacy:

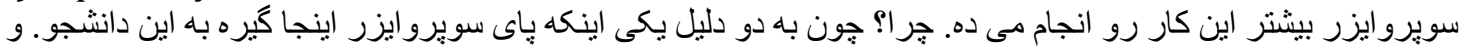

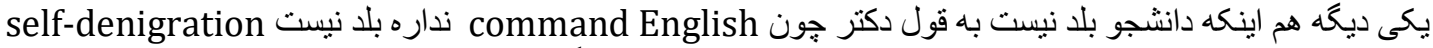

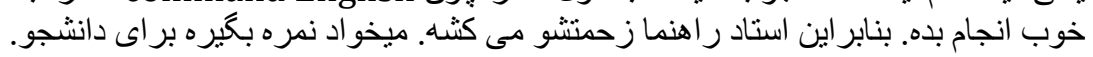

[The supervisor self-denigrates more. Why? Because of two reasons. First, the supervisor is responsible for the student. And second, the student does not know how to selfdenigrate. As Dr.... said because he/she doesn't have a good command of English and doesn't know how to self-denigrate appropriately; therefore, the supervisor takes the trouble. He/she wants to get a grade for the student.]

(10) Flamboyance:

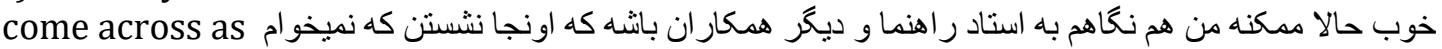

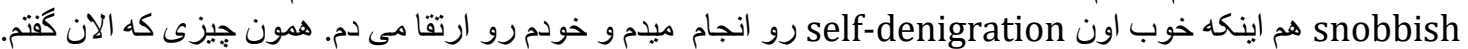

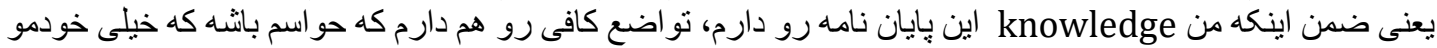
نشون ندم. proud

[Well, I might be considerate of the supervisor or my other colleagues who are sitting there because I don't want to come across as snobbish, and well, I self-denigrate and promote myself as well. It is what I just said. That is, not only do I have the knowledge of this dissertation, I am modest and careful enough not to display myself as proud.]

In order to have a more reliable understanding of self-denigration and its functions in defense sessions and validate the hypothesized model, a questionnaire was constructed to make the measurement of the attitudes of a larger population of applied linguistics academics possible. The items of the questionnaire were chosen from the participants' responses in the focus group discussions. The meaning of each function is presented in Figure 1 above which was extracted from the careful categorization and classification of the codes. 


\subsection{Quantitative analysis: Validating the conceptual model}

Two hundred and eighteen respondents completed the four-point Likert scale questionnaire. This section presents the validity of the hypothesized model using CFA. The aim was to determine the conformity of the conceptual model constructed in the qualitative phase of the study with the results of the quantitative data collection and analysis. In fact, the theoretical model was compared with the reality model to see how well the data fits.

Multi-level CFA was conducted in this study as some of the factors had subcategories with lower levels of abstraction. The first-order CFA dealt with the relationship between the lower level variables (the questionnaire responses) and the 10 functions of self-denigration. According to the results of the qualitative phase, seven factors were categorized under two main factors with a higher level of abstraction, namely, Social Decorum and Contrived Modesty for which a secondorder CFA was conducted. Second-order CFA was performed because in this model some of the factors or lower level variables are themselves latent variables. As said earlier, the first five factors were categorized under Social Decorum as their higherorder latent variable. Similarly, Evasion and Diplomacy were regarded as the subcategories of Contrived Modesty. Therefore, these two factors were assessed separately through conducting a second-order CFA. The third-order CFA assessed the relationship between the five main functions of self-denigration (Social Decorum, Diffidence, Flamboyance, Contrived Modesty, and Coercive Self-deprecation) and evaluated the whole model. The following sections present the assessment of the measurement models and the structural models at different levels.

\subsubsection{First-order CFA}

To identify the degree of accuracy of the components and the relationship between the indicators and the latent variables, the first-order CFA was performed. In the first-order CFA, if the absolute values of the factor loadings of each of the indicators corresponding to the hidden variable are greater than .7, the measurement model will be homogenous. Some scholars suggest deleting indicators with factor loadings less than .40 (Fornell \& Larcker, 1981), or .32 (Tabachnick \& Fidell, 2013). If the loading value is less than .70, the number of the indicators are few, and the Average Variance Extracted (AVE) for each construct is greater than .50, then the indicators can be retained (Fornell \& Larcker, 1981). It is necessary to see if the indicators provide a consistent and precise measure of the construct. To that end, the factors were divided into three sections, Social Decorum with its latent variables, Contrived Modesty with its subcategories, and the rest of the factors with no subsets.

If the loadings of each factor with its construct ( $t$-value) is positive and greater than 1.96 at .05 level and greater than 2.58 at .000 level, the indicator can measure the latent variable precisely (Fornell \& Larcker, 1981). As can be seen in Table 3, all the items except items 3 and 12, for the measurement model of Social Decorum 
showed acceptable factor loadings. To put it in another way, the t-value corresponding to each factor loading is higher than its critical value which equals 2.58 at 0.000 level. As a result, it can be inferred that these indicators have the appropriate precision for the measurement of the latent components of Social Decorum, and hence can be used in the final analysis (Figures 3 and 4).

\begin{tabular}{|c|c|c|c|c|c|}
\hline Factor & Item & Loading & t-value & Sig & Result \\
\hline \multirow{4}{*}{ Good manners } & Q1 & .82 & 9.69 & .000 & $\checkmark$ \\
\hline & Q2 & .74 & 7.31 & .000 & $\checkmark$ \\
\hline & Q3 & .22 & 1.36 & .172 & $\mathrm{X}$ \\
\hline & Q4 & .56 & 4.78 & .000 & $\checkmark$ \\
\hline \multirow{4}{*}{ Modesty } & Q5 & .80 & 26.83 & .000 & $\checkmark$ \\
\hline & Q6 & .44 & 4.03 & .000 & $\checkmark$ \\
\hline & Q7 & .83 & 22.46 & .000 & $\checkmark$ \\
\hline & Q8 & .82 & 27.68 & .000 & $\checkmark$ \\
\hline \multirow{4}{*}{ Affability } & Q9 & .79 & 20.90 & .000 & $\checkmark$ \\
\hline & Q10 & .85 & 32.99 & .000 & $\checkmark$ \\
\hline & Q11 & .80 & 24.39 & .000 & $\checkmark$ \\
\hline & Q12 & .28 & 2.16 & .055 & $\mathrm{X}$ \\
\hline \multirow{4}{*}{ Altruism } & Q13 & .57 & 7.48 & .000 & $\checkmark$ \\
\hline & Q14 & .74 & 16.89 & .000 & $\checkmark$ \\
\hline & Q15 & .78 & 18.27 & .000 & $\checkmark$ \\
\hline & Q16 & .49 & 3.69 & .000 & $\checkmark$ \\
\hline \multirow{4}{*}{ Assertiveness } & Q17 & .84 & 32.23 & .000 & $\checkmark$ \\
\hline & Q18 & .75 & 13.64 & .000 & $\checkmark$ \\
\hline & Q19 & .69 & 11.45 & .000 & $\checkmark$ \\
\hline & Q20 & .67 & 11.21 & .000 & $\checkmark$ \\
\hline
\end{tabular}

Table 3. Factor loadings and t-values of the measurement model of Social Decorum

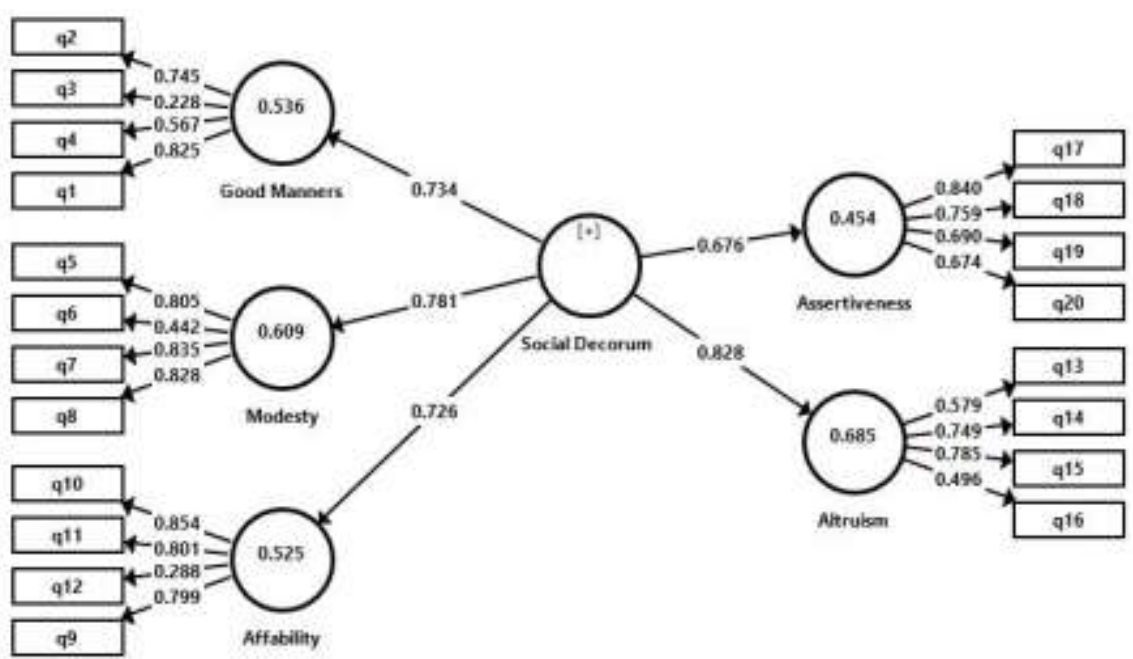

Figure 3. Factor loadings of the measurement model of Social Decorum 


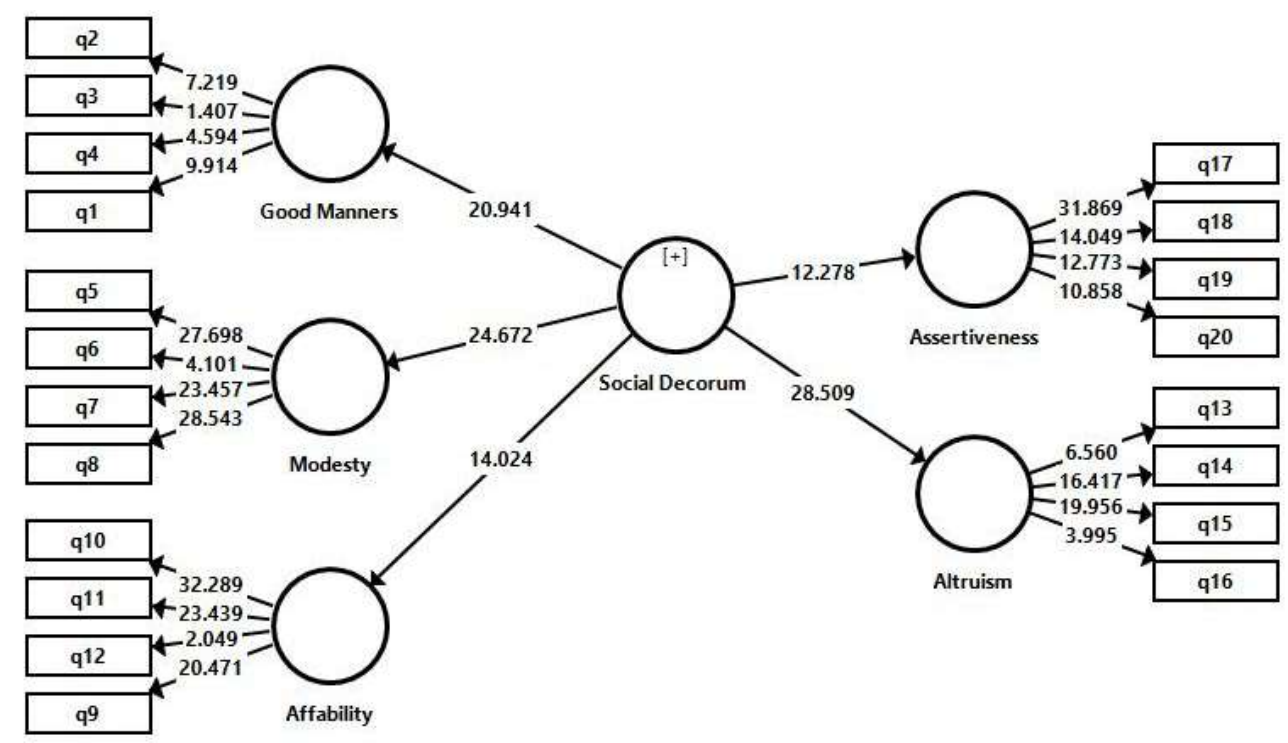

Figure 4. T-values of the measurement model of Social Decorum

Similar to the first factor, the measurement model of Contrived Modesty was assessed separately using first-order CFA. As can be seen in Table 4, all the items except item 31 showed acceptable factor loadings for Contrived Modesty. Therefore, all the other indicators can be kept in the final analysis because they enjoy the appropriate precision for the measurement of the latent variables (Figures 5 and 6).

\begin{tabular}{|c|c|c|c|c|c|}
\hline Factor & Item & Loading & t-value & Sig & Result \\
\hline \multirow{5}{*}{ Evasion } & Q29 & .85 & 36.82 & .000 & $\checkmark$ \\
\cline { 2 - 6 } & Q30 & .85 & 41.48 & .000 & $\checkmark$ \\
\cline { 2 - 6 } & Q31 & .18 & 1.52 & .050 & X \\
\cline { 2 - 6 } & Q32 & .79 & 22.19 & .000 & $\checkmark$ \\
\cline { 2 - 6 } Diplomacy & Q33 & .77 & 22.29 & .000 & $\checkmark$ \\
\cline { 2 - 6 } & Q34 & .75 & 21.61 & .000 & $\checkmark$ \\
\cline { 2 - 6 } & Q35 & .75 & 16.61 & .000 & $\checkmark$ \\
\hline
\end{tabular}

Table 4. Factor loadings and t-values of the measurement model of Contrived Modesty 


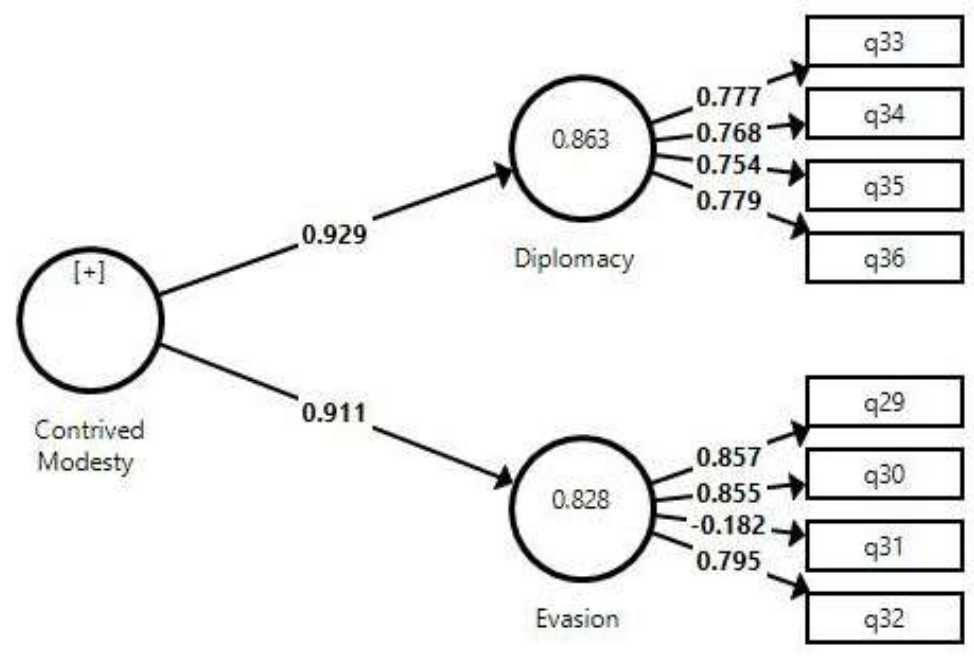

Figure 5. Factor loadings of the measurement model of Contrived Modesty

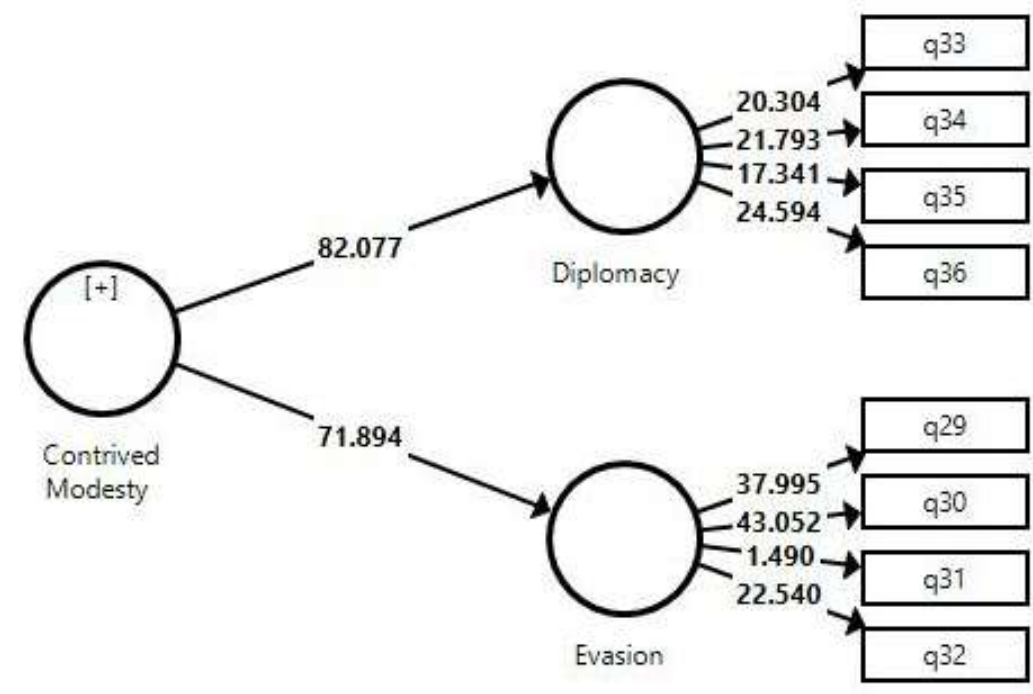

Figure 6. T-values of the measurement model of Contrived Modesty

The first-order CFA of the remaining dimensions of self-denigration, namely Coercive Self-deprecation, Diffidence, and Flamboyance, confirmed the acceptability of the indicators. Hence, according to the factor loadings and the t-values shown in Table 5, all the items can be retained in the final analysis as they have the acceptable precision for the measurement of the latent variables. These values are also shown in Figures 7 and 8. 


\begin{tabular}{|c|c|c|c|c|c|}
\hline Factor & Item & Loading & t-value & Sig & Result \\
\hline \multirow{4}{*}{$\begin{array}{c}\text { Coercive Self- } \\
\text { deprecation }\end{array}$} & Q21 & .55 & 3.98 & .000 & $\sqrt{ }$ \\
\hline & Q22 & .85 & 7.32 & .000 & $\sqrt{ }$ \\
\hline & Q23 & .61 & 3.97 & .000 & $\checkmark$ \\
\hline & Q24 & .83 & 7.73 & .000 & $\checkmark$ \\
\hline \multirow{4}{*}{ Diffidence } & Q25 & .82 & 19.20 & .000 & $\checkmark$ \\
\hline & Q26 & .84 & 18.78 & .000 & $\checkmark$ \\
\hline & Q27 & .80 & 17.98 & .000 & $\checkmark$ \\
\hline & Q28 & .76 & 16.66 & .000 & $\checkmark$ \\
\hline \multirow{4}{*}{ Flamboyance } & Q37 & .82 & 22.73 & .000 & $\checkmark$ \\
\hline & Q38 & .74 & 13.32 & .000 & $\checkmark$ \\
\hline & Q39 & .86 & 38.69 & .000 & $\checkmark$ \\
\hline & Q40 & .84 & 40.56 & .000 & $\checkmark$ \\
\hline
\end{tabular}

Table 5. Factor loadings and t-values of the measurement model of Coercive Self-deprecation, Diffidence, and Flamboyance

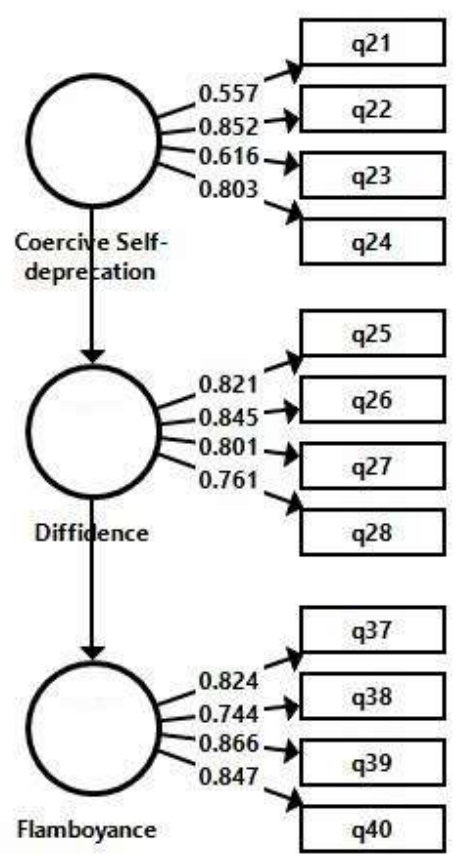

Figure 7. Factor loadings of the measurement model of Coercive Self-deprecation, Diffidence, and Flamboyance 


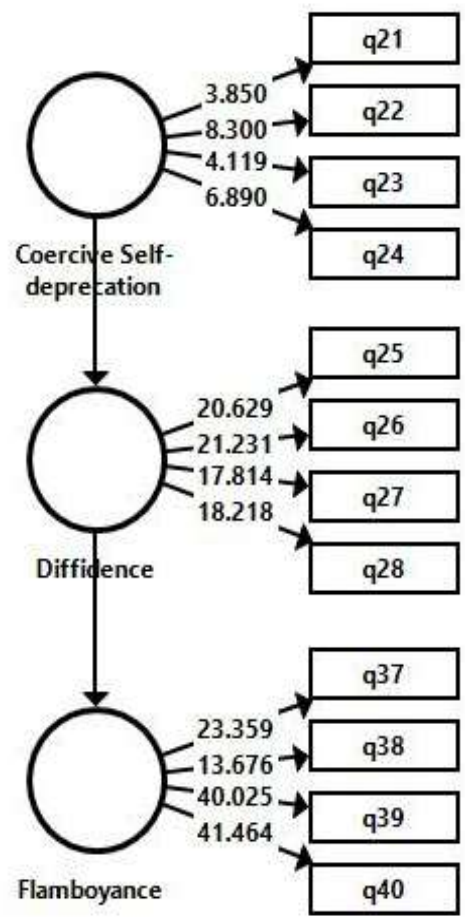

Figure 8. T-values of the measurement model of Coercive Self-deprecation, Diffidence, and Flamboyance

Given the above, according to the results of the first-order CFA, only three indicators (i.e. 3,12 , and 31 ) did not have acceptable factor loadings and had to be considered for deletion from the hypothesized model of self-denigration in the final instrument (see the Appendix). The removed indicators are as follows:

3. Self-denigration in defense sessions is a cultural issue and is mainly performing social ritual

12. The purpose of self-denigration in defense sessions might be complimenting an interlocutor

31. Self-denigration in defense sessions is a kind of patience

In addition to CFA, composite reliability, convergent validity, and discriminant validity of the measurement model were also assessed. Composite reliability was used for assessing the internal consistency reliability of the model. Composite reliability measures greater than .70 are indicative of acceptable reliability. Its values (Dillon-Goldstein's rho) for all the variables associated with the components of self-denigration were found to be greater than the criterion, so the reliability of the measurement model was confirmed (Table 6).

To verify the convergent validity of the variables, the AVE coefficient was calculated. In order to be a valid model, the lowest $50 \%$ of the variance from the 
observable variables should be taken by the latent constructs in the model. According to the estimated values of the index given in Table 6, all of the AVE values exceeded 0.50 , so convergent validity was confirmed and the measurement model enjoyed good internal consistency.

\begin{tabular}{|c|c|c|}
\hline Factor & Composite Reliability & AVE \\
\hline Good Manners & .70 & .58 \\
\hline Modesty & .82 & .52 \\
\hline Affability & .79 & .65 \\
\hline Altruism & .75 & .50 \\
\hline Assertiveness & .83 & .65 \\
\hline Coercive Self-deprecation & .80 & .51 \\
\hline Diffidence & .88 & .65 \\
\hline Evasion & .74 & .59 \\
\hline Diplomacy & .85 & .53 \\
\hline Flamboyance & .89 & .67 \\
\hline
\end{tabular}

Table 6. The composite reliability and AVE values of the structural model

The discriminant validity of the factors was calculated using Fornell-Larcker criterion test by the examination of the cross-loadings. According to the FornellLarcker index, the square root of the AVE for each latent construct should be higher than the correlations of other latent variables. As illustrated in the following tables, the square root of AVE for each latent variable surpassed the maximum correlation of the latent variables, implying the satisfactory discriminant validity of the measurement model for all the factors (Tables 7, 8, and 9).

\begin{tabular}{|c|c|c|c|c|c|}
\hline Factor & Affability & Altruism & Assertiveness & Good Manners & Modesty \\
\hline Affability & .80 & & & & \\
\hline Altruism & .59 & .70 & & & \\
\hline Assertiveness & .37 & .44 & .80 & & \\
\hline Good manners & .39 & .48 & .37 & .76 & \\
\hline Modesty & .35 & .57 & .35 & .58 & .74 \\
\hline
\end{tabular}

Table 7. The results of the Fornell-Larcker index for the discriminant validity of the structural model of Social Decorum

\begin{tabular}{|c|c|c|}
\hline Factor & Diplomacy & Evasion \\
\hline Diplomacy & .77 & \\
\hline Evasion & .69 & .73 \\
\hline
\end{tabular}

Table 8. The results of the Fornell-Larcker index for the discriminant validity of the structural model of Contrived Modesty 


\begin{tabular}{|c|c|c|c|}
\hline Factor & Coercive Self-deprecation & Diffidence & Flamboyance \\
\hline Coercive Self-deprecation & .71 & & \\
\hline Diffidence & .30 & .80 & \\
\hline Flamboyance & .29 & .48 & .82 \\
\hline
\end{tabular}

Table 9. The results of the Fornell-Larcker index for the discriminant validity of the structural model of Coercive Self-deprecation, Diffidence, and Flamboyance

\subsubsection{Second-order CFA}

As stated earlier, seven factors were teased out under the two latent variables of Social Decorum and Contrived Modesty for which a second-order CFA was conducted. Second-order factor analysis is performed because in this model the lower level variables are themselves latent variables which in turn affect the observable variables (i.e. the indicators). The first step in this stage is assessing the quality of the measurement model which was calculated by the cross-validated communality (CV Com) index. In fact, this index measures the ability of the path model in predicting observable variables through their corresponding hidden variable values. Positive CV Com value indicates an appropriate reflective measurement model. As is seen in Table 10, the CV Com values for the latent variables are positive and high which confirm the quality of the measurement model of both factors.

\begin{tabular}{|r|r|c|}
\hline \multicolumn{2}{|c|}{ Factors } & CV Com \\
\hline \multirow{4}{*}{ Social Decorum } & Good Manners & .45 \\
\cline { 2 - 3 } & Modesty & .55 \\
\cline { 2 - 3 } & Affability & .40 \\
\cline { 2 - 3 } & Altruism & .53 \\
\hline \multirow{2}{*}{ Contrived Modesty } & Assertiveness & .35 \\
\cline { 2 - 3 } & Evasion & .48 \\
\cline { 2 - 3 } & Diplomacy & .35 \\
\hline
\end{tabular}

Table 10. The cross-validated commonality index of the measurement model of Social Decorum and Contrived Modesty

As Table 11 demonstrates, the factor loading values in the second-order factor analysis are desirable. The composite reliability values indicate high internal consistency of the variables. The AVE value also confirms the convergent validity of the model. To measure the relationship between the variance explained for the latent variable with the total variance, the coefficient of determination or $\mathrm{R}^{2}$ which is bound between 0.0 and 1.0 was calculated. Values which are closer to 1.0 are more 
desirable. A value of 1.0 indicates a perfect fit, and is thus a highly reliable model for future forecasts. $\mathrm{R}^{2}$ values equal to $.19, .33$, and .67 are described as weak, moderate, and substantial, respectively. The $\mathrm{R}^{2}$ values for the factors of Social Decorum were found to be good in the estimated model (Table 11).

\begin{tabular}{|c|c|c|c|c|c|c|c|}
\hline Factor & Loading & t-value & Sig & $\mathrm{R}^{2}$ & AVE & Pc & Alpha \\
\hline Good manners & .73 & 22.95 & .000 & .53 & \multirow{5}{*}{.57} & \multirow{5}{*}{875} & \multirow{5}{*}{.872} \\
\hline Modesty & .78 & 24.45 & .000 & .60 & & & \\
\hline Affability & .72 & 14.92 & .000 & .52 & & & \\
\hline Altruism & .83 & 27.04 & .000 & .68 & & & \\
\hline Assertiveness & .67 & 13.15 & .000 & .45 & & & \\
\hline
\end{tabular}

Table 11. The results of the second-order CFA of Social Decorum

The quality of the structural model was evaluated using cross-validated redundancy (CV Red) coefficient in which values greater than 0 show that the observed values are well-constructed, indicating the predictive ability of the structural model. In other words, if the CV Red values are positive, the structural model enjoys satisfactory quality. CV Red values equal to .02, .15, and .35 are described as weak, moderate, and substantial, respectively. The CV Red coefficients in all variables are positive and greater than .35 which indicate high quality of the structural model (i.e., good manners $=.38$, modesty $=.45$, affability $=.37$, altruism $=.46$, and assertiveness $=.35$ ).

The second-order CFA was also performed for Contrived Modesty. As is shown in Table 12, the factor loading values in the second-order CFA of Contrived Modesty were also desirable.

\begin{tabular}{|c|c|c|c|c|c|c|c|}
\hline Factor & Loading & $\mathrm{t}$-value & Sig & $\mathrm{R}^{2}$ & AVE & Pc & Alpha \\
\hline Diplomacy & .92 & .79 & .000 & .86 & \multirow{2}{*}{.57} & \multirow{2}{*}{.85} & \multirow{2}{*}{.79} \\
\hline Evasion & .91 & .70 & .000 & .82 & .52 \\
\hline
\end{tabular}

Table 12. The results of the second order CFA of Contrived Modesty

\subsubsection{Third-order CFA}

The third-order CFA assessed the relationship between the five main functions of self-denigration. The following are the values of factor loadings and the t-tests of the third-order CFA. As indicated in Table 13, the factor loadings were adequate. The high values of composite reliability and Cronbach's Alpha indicate acceptable internal consistency. The value of AVE also confirms the convergent reliability of the total model. The $\mathrm{R}^{2}$ values for each of the factors of the model were also at appropriate levels (Figures 9 and 10). 


\begin{tabular}{|c|c|c|c|c|c|c|c|}
\hline Factor & Loading & t-value & Sig & $\mathrm{R}^{2}$ & AVE & $\mathrm{Pc}$ & Alpha \\
\hline Social Decorum & .53 & 3.68 & .000 & .32 & \multirow{5}{*}{.52} & \multirow{5}{*}{.85} & \multirow{5}{*}{.72} \\
\hline $\begin{array}{l}\text { Coercive Self- } \\
\text { deprecation }\end{array}$ & .60 & 12.91 & .000 & .36 & & & \\
\hline Diffidence & .74 & 22.87 & .000 & .54 & & & \\
\hline Contrived Modesty & .92 & 61.64 & .000 & .86 & & & \\
\hline Flamboyance & .72 & 16.55 & .000 & .51 & & & \\
\hline
\end{tabular}

Table 13. The results of the third-order CFA of the total model of Self-denigration

The CV Red coefficient for the model was also calculated to determine the quality of the structural model. The CV Red coefficient in all variables was close to or greater than .35 which indicated good quality of the conceptualized model (i.e., social decorum $=.35$, coercive self-deprecation $=.37$, diffidence $=.32$, contrived modesty $=.39$, flamboyance $=.33$ ). The loadings and the $t$-values of the factors of the total model are shown in Figures 9 and 10.

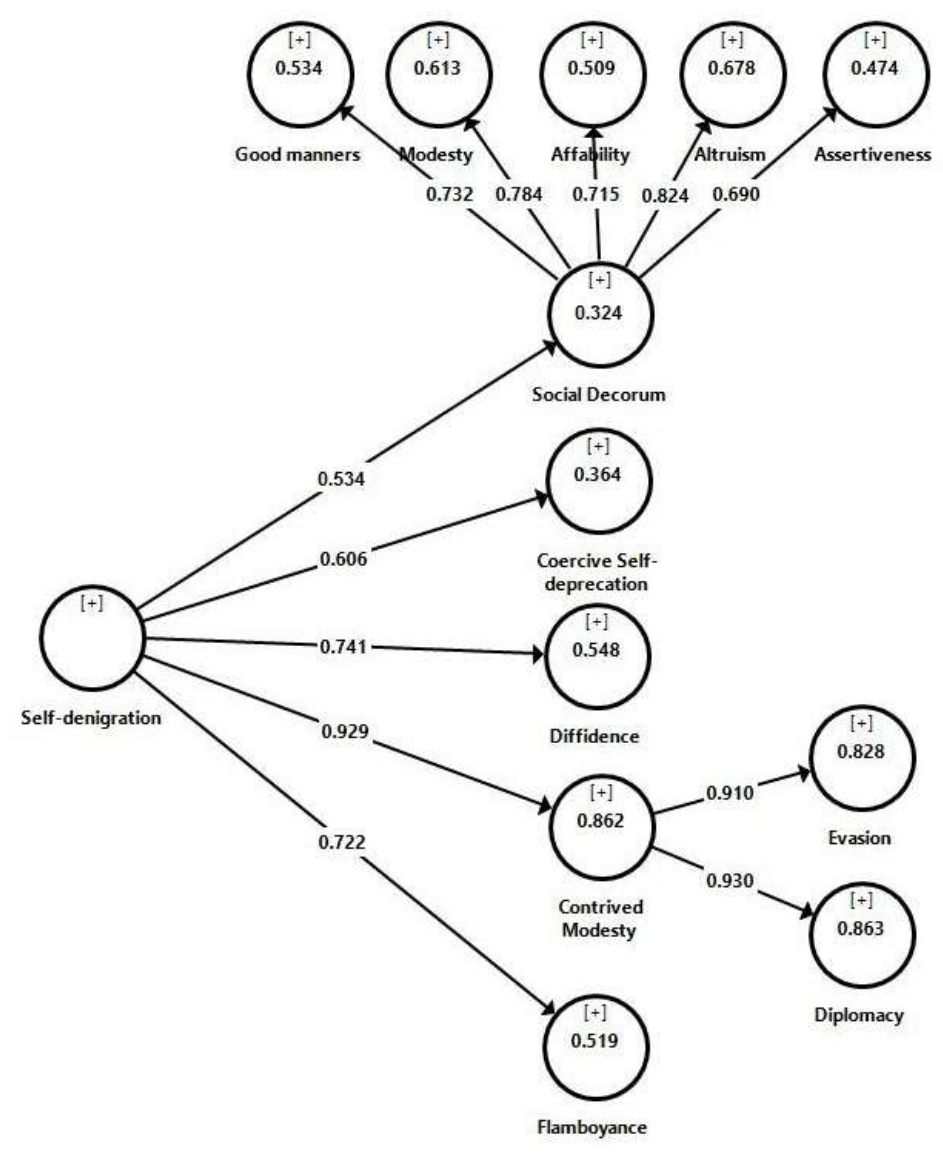

Figure 9. Factor loadings of the total model of Self-denigration 


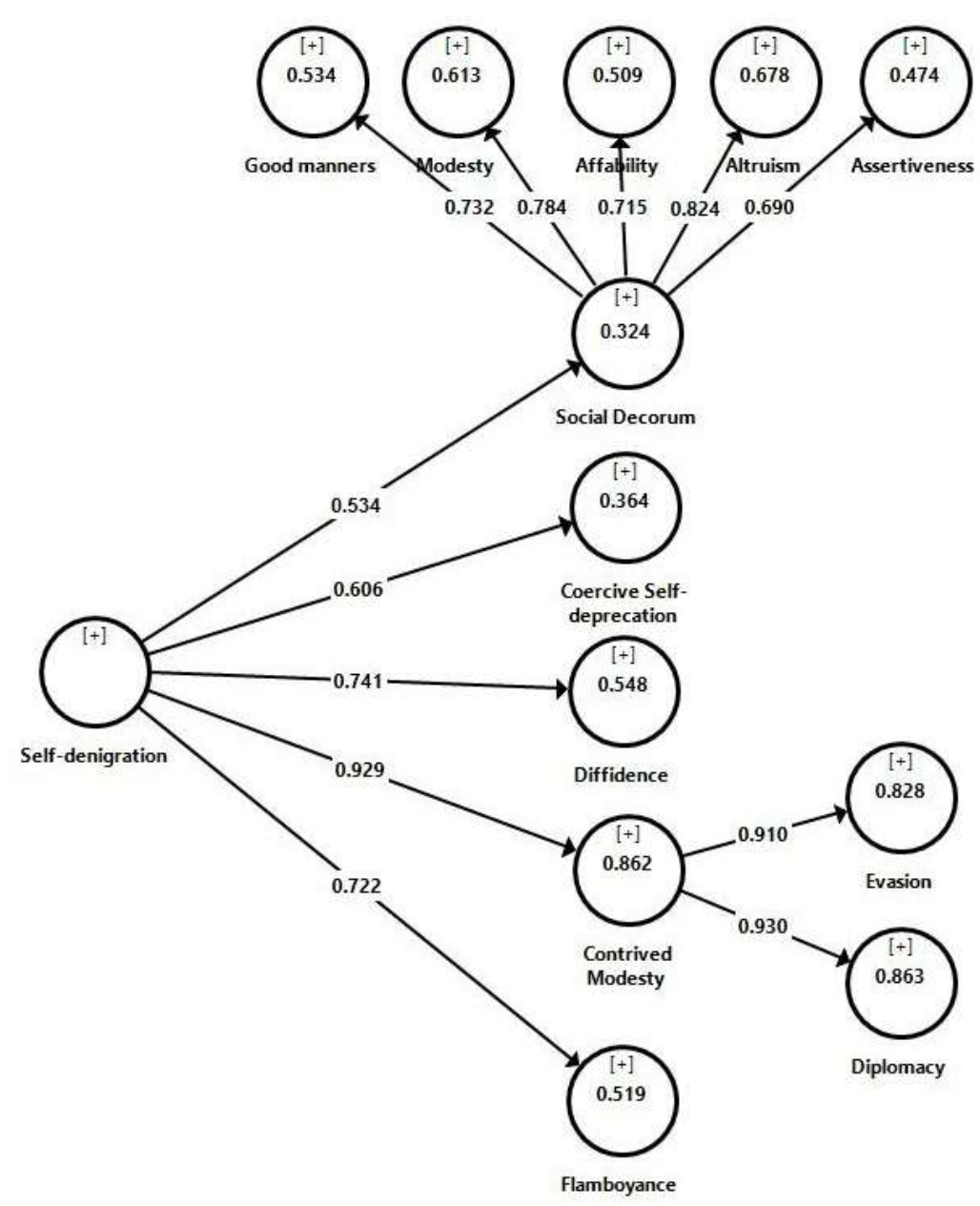

Figure 10. T-values of the total model of Self-denigration

\section{CONCLUSION}

This mixed-methods research investigated the perceptions of applied linguistics academics toward self-denigration. The evaluation of the attitudes of the defense session participants is important in that it raises the discourse communities' pragmatic awareness with respect to the norms, conventions, and expectations of this context. This consciousness-raising is particularly beneficial for EFL learners in the criticism-generating and conflict-prone context of a defense session. The qualitative aspect of this study allowed the in-depth exploration of the ideas and experiences of the applied linguists. What emerged from the qualitative analysis of the data is that self-denigration in defense sessions is the social representation of the participants' values, ideas, metaphors, beliefs, and practices which can be traced within social constructionism and symbolic interactionism. Because as was implied in the focus group participants' ideas, almost in all instances, the purpose of self- 
denigration is "to establish social order, orient participants and enable communication among members of groups and communities" (Sammut \& Howarth, 2014: 1800).

The results of the validation of the questionnaire confirmed that the instrument is suitable for evaluating the attitudes and perceptions of applied linguists concerning the meanings and functions of self-denigration in doctoral defense sessions. All the functions and indicators were found to be valid and reliable except the items representing self-denigration as social ritual, complimenting, or patience. Considering the importance of these three concepts in Iranian culture, further research is certainly needed to investigate these notions and the potential reasons for their rejection by the questionnaire respondents.

As the boundaries of self-denigration have moved away from relatively narrow considerations of showing deference and modesty (Kádár \& Zhou, 2021), more research on self-denigration would be desirable. The questionnaire developed in this study can be used to explore other contexts where hierarchical power relations affect the behaviors of the individuals and make the distinguishing between polite and politic tricky. Furthermore, it is a question of future research to investigate selfdenigration in other disciplines, languages, and other settings such as job interviews, television interviews, and doctoral program entrance interviews to test the fitness of the model proposed in this study to see how it might apply to those settings.

[Paper submitted 11 Aug 2021]

[Revised version received 9 Nov 2021]

[Revised version accepted for publication 18 Nov 2021]

\section{References}

Allami, H., \& Montazeri, M. (2012). Iranian EFL learners' compliment responses. System, 40(4), 466-482. https://doi.org/10.1016/j.system.2012.10.010

Arundale, R. B. (2020). Communicating and relating: Constituting face in everyday interacting. Oxford University Press.

Boomsma, A. (1985). Nonconvergence, improper solutions, and starting values in LISREL maximum likelihood estimation. Psychometrika, 50, 229-242.

Charmaz, K. (2014). Constructing grounded theory (2nd ed.). Sage.

Cohen, L., Manion, L., \& Morrison, K. (2007). Research methods in education (6th ed.). Routledge.

Creswell, J. W. (2012). Educational research: Planning, conducting and evaluating quantitative and qualitative research (4th ed.). Pearson.

Don, Z. M., \& Izadi, A. (2011). Relational connection and separation in Iranian dissertation defenses. Journal of Pragmatics, 43(15), 3782-3792. https://doi.org/10.1016/j.pragma.2011.09.010

Drbseh, M. (2015). The use of English compliments and compliment responses by the Arab students at Jordan University in Jordan. International Journal of Science and Research Publication, 5(12), 230-235. Retrieved from http://www.ijsrp.org/research-paper1215/ijsrp-p4836.pdf

Eslami, Z. R., Jabbari, N., \& Kuo, L. (2019). Online compliments of Iranian Facebook users. In E. Ogiermann, \& P. G. Blitvich (Eds.), From speech acts to lay understandings of politeness: Multilingual and multicultural perspectives (pp. 68-92). Cambridge University Press. 
Fornell, C., \& Larcker, D. F. (1981). Evaluating structural equation models with unobservable variables and measurement error. Journal of American Marketing Research, 18(1), 3950. https://doi.org/10.2307/3151312

Galloway, N. (2020). Focus groups: Capturing the dynamics of group interaction. In J. McKinley, \& H. Rose (Eds.), The Routledge handbook of research methods in applied linguistics (pp. 290-301). Routledge.

Gatignon, H. (2010). Confirmatory factor analysis. In H. Gatignon (Ed.), Statistical analysis of management data (pp. 59-122). Springer.

$\mathrm{Gu}, \mathrm{Y}$. (1990). Politeness phenomena in modern Chinese. Journal of Pragmatics, 14(2), 237257. https://doi.org/10.1016/0378-2166(90)90082-0

Hadley, G. (2017). Grounded theory in applied linguistics research: A practical guide. Routledge.

Hay, J. (2001). The pragmatics of humor support. Humor, 14(1), 55-82. https://doi.org/10.1515/humr.14.1.55

Hughes, D., \& DuMont, K. (1993). Using focus groups to facilitate culturally anchored research. American Journal of Community Psychology, 21(6), 775-806. https://psycnet.apa.org/doi/10.1007/BF00942247

Izadi, A. (2016). Over-politeness in Persian professional interactions. Journal of Pragmatics, 102,13-23. https://doi.org/10.1016/j.pragma.2016.06.004

Johanson, G. A., \& Brooks, G. P. (2009). Initial scale development: Sample size for pilot studies. Educational and Psychological Measurement, 70(3), 394-400. https://doi.org/10.1177/0013164409355692

Kádár, D. Z. (2010). Exploring the historical Chinese polite denigration/elevation phenomenon. In J. Culpeper, \& D. Z. Kádár (Eds.), Historical (im)politeness (pp. 117145). Peter Lang.

Kádár, D. Z. (2013). Relational rituals and communication: Ritual interaction in groups. Palgrave Macmilan.

Kádár, D. Z. (2019). Politeness and impoliteness in Chinese discourse. In C. Shei (Ed.), The Routledge handbook of Chinese discourse analysis (pp. 203-215). Routledge.

Kádár, D. Z., \& Zhou, L. (2021). Self-denigration in 21st century Chinese. Journal of Politeness Research, 17(2), 265-289. https://doi.org/10.1515/pr-2018-0043

Kim, M.-H. (2014). Why self-deprecating? Achieving 'oneness' in conversation. Journal of Pragmatics, 69, 82-98. https://doi.org/10.1016/j.pragma.2014.03.004

Krueger, R. A., \& Casey, M. A. (2015). Focus groups: A practical guide for applied research (5th ed.). Sage.

Leech, G. N. (2014). The pragmatics of politeness. Oxford University Press.

MacCallum, R. C., \& Austin, J. T. (2000). Applications of structural equation modeling in psychological research. Annual Review of Psychology, 51, 201-226. https://doi.org/10.1146/annurev.psych.51.1.201

Marsh, H. W., \& Hau, K. T. (1999). Confirmatory factor analysis: Strategies for small sample sizes. Statistical Strategies for Small Sample Research, 1, 251-284.

Mežek, Š., \& Swales, J. M. (2016). PhD defences and vivas. In K. Hyland, \& P. Shaw (Eds.), The Routledge handbook of English for academic purposes (pp. 361-375). Routledge.

Moscovici, S. (1973). Foreword. In C. Herzlich (Ed.), Health and illness: A social psychological analysis (pp. ix-xiv). Academic Press.

Page, R. (2019). Self-denigration and the mixed messages of 'ugly' selfies in Instagram. Internet Pragmatics, 2(2), 173-205. https://doi.org/10.1075/ip.00035.pag 
Sammut, G., \& Howarth, C. (2014). Social representations. In T. Teo (Ed.), Encyclopedia of critical phychology (pp. 1799-1802). Springer.

Sharifian, F. (2003). On cultural conceptualization. Journal of Cognition and Culture, 3(3), 187-207. https://doi.org/10.1163/156853703322336625

Sharifian, F. (2005). Persian cultural schema of shekasteh-nafsi: A study of compliment responses in Persian and Anglo-Australian speakers. Pragmatics \& Cognition, 13(2), 337-361. https://doi.org/10.1075/pc.13.2.05sha

Sharifian, F. (2008). Cultural schemes in L1 and L2 compliment responses: A study of Persian-speaking learners of English. Journal of Politeness Research, 4(1), 55-80. https://doi.org/10.1515/PR.2008.003

Sharifian, F. (2017). Cultural linguistics: Cultural conceptualizations and language. John Benjamins.

Singh, K., Junnarkar, M., \& Kaur, J. (2016). Measures of positive psychology, development and validation. Springer.

Speer, S. A. (2019). Reconsidering self-deprecation as communication practice. British Journal of Social Psychology, 58(4), 806-828. https://doi.org/10.1111/bjso.12329

Spencer-Oatey, H., Ng, P., \& Dong, L. (2008). British and Chinese reactions to compliment responses. In H. Spencer-Oatey (Ed.), Culturally speaking: Culture, communication and politeness theory (2nd ed.) (pp. 95-117). Continuum International Publishing Group.

Swales, J. (2004). Research genres: Explorations and applications. Cambridge University Press.

Tabachnick, B. G., \& Fidell, L. S. (2013). Using multivariate statistics (6th ed.). Pearson.

Tang, C.-H., \& Zhang, G. Q. (2009). A contrastive study of compliment responses among Australian English and Mandarian Chinese speakers. Journal of Pragmatics, 41(2), 325-345. https://doi.org/10.1016/j.pragma.2008.05.019

Trafford, V., \& Leshem, S. (2009). Doctorateness as a threshold concept. Innovations in Education and Teaching International, 46(3), 305-316. https://doi.org/10.1080/14703290903069027

Walkinshaw, I., Mitchell, N., \& Subhan, S. (2019). Self-denigration as a relational strategy in lingua franca talk: Asian English speaker. Journal of Pragmatics, 139, 40-51. https://doi.org/10.1016/j.pragma.2018.10.013

Wilkins, D. A. (1999). Applied linguistics. In B. Spolsky (Ed.), Concise encyclopedia of educational linguistics (pp. 6-17). Elsevier.

$\mathrm{Yu}$, C. (2013). Two interactional functions of self-mockery in everyday English conversations: A multimodal analysis. Journal of Pragmatics, 50(1), 1-22. https://doi.org/10.1016/j.pragma.2013.01.006

Zare, J. (2016). Self-mockery: A study of Persian multi-party interactions. Text \& Talk, 36(6), 789-812. https://doi.org/10.1515/text-2016-0034

NADIA MAYAHI is a doctoral student at Shahid Chamran University of Ahvaz, Iran. She has been an English language teacher for twenty-three years. Currently, she is the director of a student research center at Education Department in Mahshahr, where she lives. She has published and presented papers on English language teaching. Her main research interests are discourse analysis and sociology of language.

ALIREZA JALILIFAR is Professor of Applied Linguistics at Shahid Chamran University of Ahvaz, Iran, where he teaches discourse analysis, applied linguistics and advanced research. He has published and presented papers on academic discourses. He was the 
leading researcher at Shahid Chamran University of Ahvaz in 2009, 2010, and 2020. He was also included in the list of leading professionals in 2011 by the Research and Educational Department of the International Biographical Center (IBC), England. Jalilifar has supervised more than $70 \mathrm{MA}$ and $20 \mathrm{PhD}$ theses in Iran. His main interests include second language writing, genre analysis, and academic discourse.

\section{Appendix}

\section{The validated questionnaire on self-denigration in Applied Linguistics doctoral defense sessions}

\begin{tabular}{|c|c|}
\hline & Indicators \\
\hline 1 & The purpose of self-denigration in defense sessions is being polite, observing deference, and observing morality. \\
\hline 2 & $\begin{array}{l}\text { The purpose of self-denigration in defense sessions is respecting the knowledge and expertise of the examiners, } \\
\text { supervisor, or advisor. }\end{array}$ \\
\hline 3 & Self-denigration in defense sessions is used for saving self and other's face. \\
\hline 4 & Self-denigration in defense sessions is showing appreciation. \\
\hline 5 & Self-denigration in defense sessions indicates obedience and less presumptuous attitude. \\
\hline 6 & Self-denigration in defense sessions indicates lack of arrogance and egoism. \\
\hline 7 & Self-denigration in defense sessions indicates modesty and humility. \\
\hline 8 & The purpose of self-denigration in defense sessions is building relational connection with others. \\
\hline 9 & Self-denigration in defense sessions is used to build mutual trust. \\
\hline 10 & Self-denigration in defense sessions is used to maintain interpersonal relationships. \\
\hline 11 & Self-denigration in defense sessions indicates considerateness and caring for others. \\
\hline 12 & Self-denigration in defense sessions is goodwill. \\
\hline 13 & Self-denigration in defense sessions might be used for motivating others. \\
\hline 14 & Self-denigration in defense sessions might be used for approving others. \\
\hline 15 & Self-denigration in defense sessions is the projection of self-confidence. \\
\hline 16 & Self-denigration in defense sessions is the manifestation of knowledgeability and competence. \\
\hline 17 & Self-denigration in defense sessions might be used as a polite defense of one's stance and personal opinions. \\
\hline 18 & Self-denigration in defense sessions might be a technique for expressing one’s opinions vigorously. \\
\hline 19 & Self-denigration in defense sessions is an unwritten rule. \\
\hline 20 & Self-denigration in defense sessions is imposed humility. \\
\hline 21 & Self-denigration in defense sessions is essential and inevitable. \\
\hline 22 & Self-denigration in defense sessions is recommended. \\
\hline 23 & Self-denigration in defense sessions might be a sign of uncertainty. \\
\hline 24 & Self-denigration in defense sessions might indicate admitting inadequacy of knowledge. \\
\hline 25 & Self-denigration in defense sessions might indicate accepting weaknesses and shortcomings. \\
\hline 26 & Self-denigration in defense sessions might indicate seeking protection and confirmation. \\
\hline 27 & Due to the nature of the defense session, self-denigration in defense sessions is used to avoid criticism. \\
\hline 28 & $\begin{array}{l}\text { The purpose of self-denigration in defense sessions, due to the critical nature of the defense session, is avoiding } \\
\text { conflict. }\end{array}$ \\
\hline 29 & Self-denigration in defense sessions is used to avoid negative consequences and punishment. \\
\hline 30 & Self-denigration in defense sessions is a kind of conservativeness. \\
\hline 31 & Self-denigration in defense sessions might be used for fulfilling one's personal purposes like getting a score. \\
\hline 32 & Self-denigration in defense sessions is used to compromise with criticisms. \\
\hline 33 & Self-denigration in defense sessions is expedient and might be fake. \\
\hline 34 & The purpose of self-denigration in defense sessions might be showing off. \\
\hline 35 & The purpose of self-denigration in defense sessions might be hypocrisy. \\
\hline 36 & The purpose of self-denigration in defense sessions might be attention-seeking. \\
\hline 37 & The purpose of self-denigration in defense sessions might be seeking praise and affection. \\
\hline
\end{tabular}

